\title{
SYSTEMATIC REVIEW ON GHUNGCHI SAFAID (ABRUS PREATORIUS) SEEDS
}

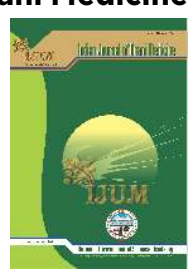

\author{
Samreen Khan ${ }^{1}$, Yasmeen Shamsi ${ }^{2} *$, Umar Jahangir ${ }^{3}$, Mukesh Manjhi ${ }^{4}$ \\ ${ }^{1}$ Department of Moalajat, Hayat Unani Medical College \& Research Centre, Lucknow, India \\ ${ }^{2}$ Department of Moalajat, School of Unani Medical Education \& Research, Jamia Hamdard, New Delhi, India \\ ${ }^{3}$ Department of Jild wa Tazeeniyat, School of Unani Medical Education \& Research, Jamia Hamdard, New Delhi, India \\ ${ }^{4}$ Department of Dermatology, Hamdard Institute of Medical Science and Research, New Delhi, India
}

\section{Review Paper}

\begin{abstract}
Ghungchi safaid (Abrus precatorius) is commonly known as Gunja or Jequirity belonging to Fabaccae- a pea family, richly found throughout plains of India, from Himalaya down to Southern India and Sri lanka. It is a semi poisonous medicine mentioned among higher degree of hot $\&$ dry temperament which is used in various diseases topically and considered as contraceptive internally in Unani System of medicine. The present review represents the classification, habitat, etymoloygy, pharmacological actions, therapeutic uses, unwarranted effects and correctives along with pharmacological studies
\end{abstract}

No. of Pages: 4

References: 37

Keywords: Abrus precatorius, Ghungchi, anti-inflammatory, vitiligo, nervine tonic.

\section{INTRODUCTION}

Abrus precatorius is an ornamental, twining, woody vine which grows to a height of 10 to 20 feet when supported by other plants (1). The branchlets of the plant of Abrus precatorius are glabrescent. Its leaves are evenpinnate, leaflets are 9-12 in pair, opposite and oblong in shape. The flowers of Abrus precatorius are sub-sessile, wide, and compact on cushion like nodes, petals are rose to pink in colour. The pink colour flowers produce red and black coloured seeds whereas white colour flowers produces white coloured seeds, having 5.2-5.5mm length and 2.7-3.7 mm width. The seeds are $3-6$ in number, ovoid, and $7.5 \mathrm{~cm}$ long scarlet with a black spot at the hilum and polished. The weight of single seed of red variety is $0.1498 \mathrm{~g}$ (approx.) and white variety is about $0.13825 g(2)$ (3).

$\begin{array}{ll}\text { Scientific classification } \\ \text { Kingdom: } & \text { Plantae-Plan } \\ \text { Subkingdom: } & \text { Tracheobionta (Vascular plants) } \\ \text { Super division: } & \text { Spermatophyta (Seed plants) } \\ \text { Division: } & \text { Magnoliophyta (Flowering plants) } \\ \text { Class: } & \text { Magnoliopsida (Dicotyledons) } \\ \text { Subclass: } & \text { Rosidae } \\ \text { Order: } & \text { Fabales } \\ \text { Family: } & \text { Fabaceae / Leguminosae (Pea family) } \\ \text { Genus: } & \text { Abrus Adans - abrus } \\ \text { Species: } & \text { Abrus precatorius L.-rosarypea (4) }\end{array}$

*Corresponding author: yshamsi@jamiahamdard.ac.in 


\section{Vernacular names and etymology}

$\begin{array}{ll}\text { Arabic: } & \text { Ainuddeek (5) (3) } \\ \text { Persian: } & \text { Chashm Kharoos (5) (3) } \\ \text { Hindi: } & \text { Ratti, Ghungchi (6) (5) (7) (3) } \\ \text { Bengali: } & \text { Kunch, Shonkainh (6) (5) } \\ \text { Gujarati: } & \text { Rati, Chanothee, Chonotee (6) (5) } \\ \text { Kannad: } & \text { Guluganji, Gulagunja (6) (5) Gunji (7) } \\ \text { Tamil: } & \text { Kunrimani, Kundumani (6) (5) (3) } \\ & \text { Gundumani (7) } \\ \text { Malayalam: } & \text { Kunni, Cuvanna Kunni (6) (5) } \\ & \text { Kakani (7) (3) } \\ \text { Marathi: } & \text { Gunja (6) (5) (3) } \\ \text { Oriya: } & \text { Kainch (8) } \\ \text { Punjabi: } & \text { Ratti (5) (3) } \\ \text { Telugu: } & \text { Guriginga, Gurivinda (5) (6) (7) (3) } \\ \text { Sanskrit: } & \text { Gunja (6) (3) } \\ \text { English: } & \text { Crab's eye, Indian liquorice, } \\ & \text { Jequirityas (9) (10) (3) }\end{array}$

\section{Habitat and Distribution}

Abrus precatorius Linn. (Fam. Papilionaceae); a climber, all along Himalayas ascending to $900 \mathrm{~m}$, spreading throughout the country; flowering in August-September, fruits ripen during winter. It is also found in South China, the Pacific Islands and tropical Africa and West Indies(5) (11) (10).

\section{Chemical constituents}

Abrin, alanine, abrusin, abrusin-2'-0-apioside, abrusgenicacid, abrusgenic-acid-methyl-ester, abrisapogenol, abrussicacid, anthocyanins, Abruslactone, $\beta$-amyrin, calcium, campesterol, choline, cycloartenol, delphinidin, dimethoxycentaureidin-7-0-rutinoside, gallic-acid, glycyrrhizin, glucodelphinidin, hederagenin, hypaphorine, iron, methyl-ester, magnesium, N,N-dimethyl-tryptophan, $\mathrm{N}, \mathrm{N}$ - dimethyl-tryptophan-methocation- $\rho$ coumaroylgalloyl pectin, pentosans, picatorine, polygalacturonic-acids, precasine, precatorine, potassium, phosphorus, sodium, serine, trigonelline, manganese, valine, zinc (1) (9) (10) (7) (3).

\section{Temperament}

- Hot $3^{\circ}$ Dry $2^{\circ(12)(13)}$

- $\operatorname{Hot} 2^{\circ}$ Dry $3^{\circ(14)}$

- Hot $2^{\circ}$ Moist $1^{\circ}$, (White variety)Hot $3^{\circ}$ Dry $2^{\circ}$ (Red Variety)(15)

- $\quad \operatorname{Hot} 3^{\circ}$ Dry $3^{\circ},(16)(17)(18)$

\section{Pharmacological Actions}

- Jali (Detergent) (18) (19)

- Muhallil (Anti-inflammatory) (19)

- Akkal(Corrosive)(19)

- Muharrik-e-Bah (Aphrosidiac) (12)(19)(15)

- Muqawwi Aasab (Nervine Tonic) (12)

- Mowallid-e-Mani (semenogogue)(15)

\section{Therapeutic Uses:}

\section{Locally}

- Due to its anti-inflammatory nature it is applied over swellings(19).

- Its powder is applied along with linseed oil to cure acne and melasma(18) (17).

- It is applied in the management of vitiligo, and taenia(19).

- Aphrodisiac when applied locally in the form of Tila (18) (17) (12) (19).

- It heals wounds and piles(18)(19)(17).

- It is used in the management of cataract (18) (17).

- Application of oil obtained from seeds is aphrodisiac and a promising nervine tonic(12).

\section{Internally}

Although, its internal use is contra-indicated, few indications are mentioned in Unani literature(17) (18)

- Contraception: taking 1 seed after bleeding phase of menstrual cycle may prevent conception for 1 year (17).

\section{Parts Used}

Seeds, leaves, stem(17)

\section{Therapeutic dose}

Quantity sufficient for local application and internally 1-2g (12) (19) (13)

\section{Unwarranted effects}

Contraindicated in people with hot temperament and old aged people(19) (12), Headache(12), Vomiting and loose motions (17)

\section{Correctives}

Kishneez sabz (Green Corriander), (15) (12) (19), Turanjabeen (Camel thorn) (12) (19), Sheerah Akash Bel (Cuscuta juice), Lassi(Butter mlk), Doodh(Milk),(17)

\section{Formulations}

Zimad Muhasa (20) (21) Majoon Malooki, Majoon Hafiz al Sehat (12)

\section{Pharmacological studies}

- Anti-bacterial activity(22)(23) 
- Anti-fungal(23)

- Anti-diabetic activity(24) (25)

- Anti-fertility activity(26)(27)(28)

- Bronchodilator activity(29)

- Anti-arthritic activity (30)

- Antioxidant(31)(32).

- Nephro-protective(33)

- Wound healing activity (34) (35)

- Anti-inflammatory(36)

- Lipase inhibitory effect(32)

\section{Conclusion}

It is clearly evident that most of the therapeutic uses of Ghunghi safaid seeds mentioned in classical Unani literature are in accordance with pharmacological studies which are conducted recently thus supporting its usage specifically in dermatology and sexology

\section{Bibliography}

1. Abrus precatorius Linn (Fabaceae): phytochemistry, ethnomedicinal uses, ethnopharmacology and pharmacological activities. Okhale, Samuel Ehiabhi and Nwanosike, Ezekwesiri Michael. 6, 2016, International Journal of Pharmaceutical Science and Research, Vol. 1, pp. 37-38.

2. Pharmacognostical studies on white and red forms of Abrus precatorius Linn. Prathyusha, P, Modurpalayam, S Subramanian and Shivakumar, R. 4, 2010, Indian Journal of Natural Products and Resources, Vol. 1, pp. 476-480.

3. Kritikar, KR and Basu, BD. Indian Medicinal Plants. [ed.] E Blatter, J F Caius and KS Mhaskar. 2. Dehradun : International Book Distributors, 1987. pp. 138, 536-41, 764-68,.

4. USDA. Plant Data Bases Abrus. [Online] 2018.

5. Anonymous. The Unani Pharmacopia of India. New Delhi : CCRUM, 2007. pp. 41-42. Vol. IV.

6. Ambasta, S P. The useful Plants of India. New Delhi : CSIR, 1992. pp. 2, 3,25, 63, 64, 228, 294.

7. Chopra, R N, Nayar, S L and Chopra, I C. Glossary of Indian Medicinal Plants. New Delhi : Council of Scientific and Industrial research, 1956. pp. 1, 10,11, 31, $122,143$.

8. Anonymous. The Unani Pharmacopia of India. New Delhi : Department of Ayurveda, Yoga \& Naturopathy, Unani, Siddha and Homoeopathy, 2007. pp. 57-58, 8182. Vol. 2.
9. Asolkar, LV, Kakkar, KK and Chakre, OJ. Glossary of Indian medicinal Plants with active Principles. New Delhi : Publications \& Information Directorate, CSIR, 1992. pp. 4-6, 36-37, 108-111,319-320, 373. Vol. 1.

10. Khare, C. Indian medicinal plants: an illustrated dictionary. New York : Springer, 2007. pp. 3, 75-76, 39, 282, 336.

11. Williamson, E M. Major Herbs of Ayurveda. s.l. : Churchill Livingstone, 2002. pp. 6-12, 56-63.

12. Abdul Hakeem, HM. Bustanul Mufradat Jadeed. New Delhi : Idara Kitab-us-Shifa, 2002. pp. 106, 336-7, 5067, 591, 598,-91.

13. Kabiruddin, HM. Ilmul Advia Nafeesi. New Delhi : Aijaz Publishing House, 2007. pp. 149-50, 300, 329.

14. Gulam Nabi, Munshi. Makhzanul Mufradat wa Murakkabat Muarrifba-Khwas-ul Advia. 2. New Delhi : CCRUM, 2007. pp. 143, 150, 157, 211, 241.

15. Abdul Haleem, Hakeem Mohammad. Mufradat Azeezi. New Delhi : CCRUM, 2009. pp. 31,76, 98.

16. Kabiruddeen, H M. Makhzanul Mufradat al Mufradat Almaroof Khwas al Advia. Delhi : Aijaz Publishing House, YNM. pp. 339-340.

17. Ghani, N. Khazainul Advia. New Delhi : Nadeem younus Printers, Lahor, YNM. pp. 15-17, 620-623, 657660, 778-781, 920-923, 962, 988-995.

18. Lubhaya, Ram. Goswami Bayan ul Advia. Delhi : Goswami pharmacy, 1984. pp. 21.22,32, 33, 34, 61, 62, 196, 197, 198, 242, 251,252, 253.

19. Kabiruddeen, H. M. Makhzanul Mufradat al Mufradat Almaroof Khwas al Advia. Delhi : Aijaz Publishing House, YNM.

20. Anonymous. Qarabadeen Majidi. Delhi : All India Unani Tibbi Conference, 1994. p. 233.

21. Khan, M.A. Qarabadeen-e-Azam. Lahore : Malik Sirajuddin, Sons, 1957.p. 157.

22. In vitro antibacterial activity and phytochemical analysis of abrus precatorius Linn,. Abbassy, A M, Masoud, A S and Nassar, K M A. 2, 2016, Egy.J. Plant Pro. Res, Vol. 4, pp. 1-14.

23. A study on phytochemicals, Fatty acid Analysis and Antimicrobial Activity of Abrus Precatorius Linn Seeds. Krishnaveni, $\mathbf{M}$, Nandhini, $\mathbf{N}$ and Dhanalakshmi, $\mathbf{R}$. 2, 2014, International Journal of Pharmaceutical Sciences Review and Research, Vol. 27, pp. 178-81.

24. Antidiabetic effect of chloroform-methanol extract of $A$. precatorius seeds in alloxan diabetic rabbit. Monago, CC and Alumanah, EO. 1, 2005, J. Appl. Sci. Environ. Mgt., Vol. 9, pp. 85 - 88. 
25. Anti-diabetic Effect of crude trigonelline of Abrus Precatorius Linn Seed in Alloxan Diabetic Rabbit. Monago, CC and Nwodo, O Fred. 8, 2010, J Pharm Res, Vol. 3, pp. 1916-19196.

26. A Preliminary Study on the Effect of Abrusprecatorius Linn on Reproductive Parametersin Female Rattusnorvegicus Wistar Strain. Ogbuehi, H I, Ebong, O O and Obianime, W A. 3, 2015, European Journal of Medicinal Plants, Vol. 7, pp. 156-66.

27. Screening of Indian plants forantifertility activity. Prakash, AO and Mathur, R. 1976, Indian Journal of Experimental Biology, Vol. 14, pp.623-626.

28. Antifertility effects of ethanolic seed extract of Abrus precatorius $L$. on sperm production and DNA integrity in adult male mice. Jahan, S, et al. 2009, J Med Plant Res, Vol. 3, pp. 809-814.

29. Investigation of The Bronchodilator Activity of Arbus Precatorius. Mensah, YA, Bonsu, S A and Fleischer, C T. 2, 2011, International Journal of Pharmaceutical Sciences Review and Research, Vol. 6, pp. 9-13.

30. Evaluation of red and white seed extracts of Abrus precatorius Linn. against freund's complete adjuvant induced arthritis in rats. Sudaroli, $\mathbf{M}$ and Chatterjee, TK. 4, 2007, Journal of Medicinal Plants Research, Vol. 1, pp. 86-94.

31. n-Vitro Antioxidative activity of Phenolic and Flavonoid compounds extracted from Seeds of Abrus Precatorius.
Pal, RS, et al. 2, 2009, Int J Pharm \& Pharm Sci, Vol. 1, pp. 136-140.

32. Evaluation of anti-acne activity of selected Sudanese medicinal plants. Muddathir, Ali Mahmoud and Mitsunaga, Tohru. 2012, Journal of Wood Science, Vol. 59, pp. 73-79.

33. Protective Effect of Abrus precatorius Seed Extract following Alcohol Induced Renal Damage. Ligha, AE, Bnrl, J and Numere, NF. 3, 2009, Eur J Sci Res., Vol. 25, pp. 428-436.

34. Evaluation of Wealing activity of red and white seed varieties of Abrus precatorius Linn. on rats. Sudroli, $\mathbf{M}$ and Chaterjee, TK. 2009, Vol. 3, pp. 175-92.

35. Studies on wound healing activity of Red and Block coloured seed, white coloured seed extracts of Abrus precatorius L. Alagesaboopathi, C and Sivakumar, R. 1, 2011, International Journal of Pharma and Bio Sciences, Vol. 2, pp. 302-12.

36. Anti-Inflammatory effects of Abrus precatorius seed extract. Eze, S.O. and Nwodo, O.F.C. 3, 2001, Nigerian Journal of Biochemistry and Molecular Biology, Vol. 16, pp. 95s-98s.

37. Investigation of Anti-Acne Potential of Leaves of Cassia fistula and Abrus precatorius. Patel, Bina S, Pandya, Devang J. and Bhatt, Parth V. 3, 2015, International Journal of PharmTech Research, Vol. 8, pp. 352-355. 